\title{
Clinical and demographic features among patients with type 1 diabetes mellitus in Henan, China
}

\author{
Liguo Yang ${ }^{1}$, Guangxing Yang ${ }^{2}$ and Xialian $\mathrm{Li}^{\mathrm{i}^{*}}$
}

\begin{abstract}
Background: The hallmark of type 1 diabetes (T1D) is an absolute lack of insulin. However, many studies showed a tendency to heterogeneity in TID. We aimed to investigate the demographic and clinical characteristics in T1D and the differences in young-onset and adult-onset patients.

Methods: This retrospective study was conducted among 1943 patients with clinically diagnosed T1D. Medical records on patients' demographics, anthropometric measurements, and clinical manifestation were collected. According to the age at onset, the newly diagnosed patients were divided into the young-onset group ( $<18$ years, 234 patients, mean age 11 years) and adult-onset group ( $\geq 18$ years, 219 patients, mean age 27 years). Pancreatic $\beta$ cell function was assessed by fasting C-peptide (FCP) and 2-h C-peptide (2-h CP).

Results: The median age of patients at disease onset was 22 years. The median duration of patients was 3 years. The overall median glycated hemoglobin (HbA1c) value was $10.3 \%[89(\mathrm{mmol} / \mathrm{mol})]$. The prevalence of diabetic retinopathy was $25.1 \%$. The overall rate of DKA at onset in the new-onset patients was $59.6 \%$. The frequency of overall dyslipidemia was $37.8 \%$. The most frequent dyslipidemia was low high-density lipoprotein-cholesterol (HDL) (29\%). The proportion of patients with anti-glutamic acid decarboxylase (GADA), insulin antibody (IAA) and islet cell antibody (ICA) were $28.1 \%, 6.4 \%$ and $21.6 \%$, respectively. The mean HbA1c showed a downward trend with age. Increasing or decreasing trends of overweight and obesity in this population during the period 2012 to 2018 was not found.

Compared with young-onset T1D, adult-onset patients comprised better islet function (FCP: $0.4 \mathrm{vs} .0 .3 \mathrm{ng} / \mathrm{ml}, P<$ $0.001 ; 2$-h CP: 0.9 vs. $0.7 \mathrm{ng} / \mathrm{ml} P<0.001$, respectively) and glycemic control $[12.9 \%(117 \mathrm{mmol} / \mathrm{mol})$ vs. $11.7 \%$ $(104 \mathrm{mmol} / \mathrm{mol}), P<0.001]$, higher prevalence of diabetes condition in the male gender $(64.4 \% \mathrm{vs} .51 .3 \%, P=0.006)$, higher proportion of obesity or overweight ( $24.6 \%$ vs. $9.5 \%, P=0.002$ ), higher frequency of GADA (33.7 \% vs. $23.3 \%, P=0.025)$, and lower frequency of diabetic ketoacidosis at disease onset $(64.5 \%$ vs. $43.5 \%, P<0.001)$.
\end{abstract}

\footnotetext{
*Correspondence: ylg2385182183@163.com

'Department of Endocrinology, The First Affiliated Hospital of Zhengzhou University, 450052 Zhengzhou, Henan, China

Full list of author information is available at the end of the article
}

(c) The Author(s). 2021 Open Access This article is licensed under a Creative Commons Attribution 4.0 International License, which permits use, sharing, adaptation, distribution and reproduction in any medium or format, as long as you give appropriate credit to the original author(s) and the source, provide a link to the Creative Commons licence, and indicate if changes were made. The images or other third party material in this article are included in the article's Creative Commons licence, unless indicated otherwise in a credit line to the material. If material is not included in the article's Creative Commons licence and your intended use is not permitted by statutory regulation or exceeds the permitted use, you will need to obtain permission directly from the copyright holder. To view a copy of this licence, visit http://creativecommons.org/licenses/by/4.0/ The Creative Commons Public Domain Dedication waiver (http://creativecommons.org/publicdomain/zero/1.0/) applies to the data made available in this article, unless otherwise stated in a credit line to the data. 


\begin{abstract}
Conclusions: This population was characterized by poor overall blood glucose control, high prevalence of DKA, dyslipidemia and diabetic retinopathy, and low prevalence of islet-related antibodies, and overweight or obesity. Adult-onset patients with T1D were not uncommon and had better clinical manifestations than young-onset patients. Any findings related to body mass index (BMI) and autoantibodies should be considered strictly exploratory due to excessive missing data.
\end{abstract}

Keywords: Type 1 diabetes, Epidemiology, Chinese

\section{Background}

Type 1 diabetes mellitus (T1D) is a chronic autoimmune disease in which endogenous insulin production is severely compromised by an immune-mediated injury of pancreatic $\beta$-cells[1]. The estimations of T1D incidence based on population-based registries showed a variation in the incidence all over the world during the past 2 decades. On the whole, the incidence around the world has been on the rise[2-5], but the incidence in some countries is decreasing, such as Finland[6]. The epidemiological data from China showed that the incidence of T1D has been on the rise[7-9]. George Eisenbarth put forward a conceptional model for the pathogenesis of T1D before 30 years. It held that both environmental risk and genetic susceptibility promote the development of T1D. However, the rise in incidence is too rapid to be explained by increased transmission of susceptibility haplotypes from one generation to the next. Furthermore, some studies manifested that as time goes on, high-risk HLA genotypes were becoming not so frequent as before in youth with $\mathrm{T} 1 \mathrm{D}[10,11]$. Therefore, the increasing environmental pressure may play an increasingly important role in the occurring of T1D. There are many environmental factors, such as obesity, infant and adult diet, vitamin D deficiency, early exposure to islet immune-related viruses (such as enterovirus) and the decline of intestinal microbial diversity. These are still incompletely understood.

T1D is one of the most common chronic diseases of childhood, but it can occur at any age, even in the 8th and 9th decades of life[12]. American Diabetes Association (ADA) reported that the patients of adult-onset T1D was increasing and with up to $50 \%$ of cases occurred in adulthood [13]. A study in China reported that $65.3 \%$ cases of new-onset T1D occurred among adults[14]. Age of onset is a major driver of T1D heterogeneity [15]. Previous studies showed that patients presenting with T1D in adults were characterized by a longer symptomatic period before diagnosis, a better preserved $\beta$-cell function, and a reduced frequency of IAA, compared with young-onset subjects.

Considerable heterogeneity exists in clinical, immunologic and epidemiological characteristics of T1D based on ethnicity and country[15-17]. According to Multinational Project for Childhood Diabetes (DIAMOND), the Chinese is among populations with the lowest incidence of T1D [18], maybe resulting from the counterbalancing between protective DQB1 and susceptible DRB1[19]. However, in China, a region with large population base, a linear increase in diabetes incidence may lead to a substantial increase in the number of patients with T1D. It will eventually bring about a major increase in the estimated health expenditure which have a great economic impact on individuals and their families[20]. Therefore, it is of great value to investigate the situation of hospitalized patients for recognizing and addressing preventable medical problems. Consequently, we aim to investigate demographic, clinical characteristics of patients with T1D, as well as the pattern of being overweight or obesity changes in Henan in recent years.

\section{Materials and methods \\ Study design}

This was a hospital-based, retrospective study from the first affiliated hospital of Zhengzhou university that is a tertiary medical center in Zhengzhou city, Henan Province, China. Inpatients in this hospital included urban as well as rural population. The participants in our study covered both pediatric and adult patients with T1D who were diagnosed and treated by pediatricians or endocrinologists. Quite a few patients spent the critical period in the emergency department due to diabetic ketoacidosis before transferring to the general ward.

The medical records of T1D among all inpatients in our hospital from Jan 2012 to Dec 2018 were reviewed in hospital information system. All study patients had the diagnosis of T1D made by endocrinologists and documented in the hospital's case database. We retrospectively evaluated all patients' medical records and collected data on patients' demographics, clinical manifestations, and metabolic indicators. Proteinuria and urine acetone bodies were assessed by presenting protein and (or) acetone bodies in urine routine examination (clean and interrupted morning urine was collected, and then was checked by an automatic analyzer). Retinopathy was defined by hemangioma, exudation, bleeding, or more serious proliferative lesions on one or both sides of the fundus from retinal photographs.

The study was carried out in compliance with the declaration of Helsinki. The study was approved by the 
Ethical Committee of the First Affiliated Hospital of Zhengzhou University (Number: 2020-KY-417). Because this was a retrospective observational study, and deidentified information was used for the analysis, informed consents were waived as part of the Institutional Review Board of the First Affiliated Hospital of Zhengzhou University approval.

\section{Study population}

The inclusion criteria for T1D patients were determined by clinical characteristics. Based on the World Health Organization (WHO) reports for the classification of diabetes[21], the ADA descriptions of T1D[12], all participants should be dependent on insulin at disease onset, diagnosed with T1D by an endocrinologist, and met at least 1 of the followings: (1) classic symptoms of diabetes-related metabolic disorders at disease onset, (2) fasting C-peptide levels $<0.60 \mathrm{ng} / \mathrm{ml}$ at initial diagnosis[22], (3) recurrent diabetic ketosis or ketoacidosis, (4) being positive for one or more of diabetes-related autoantibodies. If the diagnosis was uncertain, they will be further confirmed by expert committee for final judgement. Nine patients diagnosed with diabetes before age 6 months were excluded from the analysis. Fifty patients were excluded from the study because all laboratory test results could not be found in the inpatient system. Eventually 1943 T1D patients were enrolled in this study. The number of patients with different variables included in this study, may vary due to missing data.

In this study, patients aged 18 or above were defined as adults. Patients under 18 is defined as a child or adolescent. For 453 newly diagnosed patients with T1D, according to the age of onset, it was divided into the young-onset group ( $<18$ years, 234 patients) and adultonset group ( $\geq 18$ years, 219 patients).

\section{Measurement and Definition}

Body mass index (BMI) was calculated using the measured weight $(\mathrm{kg})$ divided by the square of measured height (m). Age-specific and sex-specific BMI criteria for overweight and obese categories for children and adolescents aged $<18$ years were derived from the International Obesity Task Force (IOTF definition). For patients aged $\geq 18$ years, overweight and obesity were categorized according to WHO criteria for Asian population as $\mathrm{BMI} \geq 23$ to $<27.5 \mathrm{~kg} / \mathrm{m}^{2}$ and $\geq 27.5 \mathrm{~kg} / \mathrm{m}^{2}$, respectively.

Chinese Guidelines on Prevention and Treatment of Dyslipidemia in Adults cut-offs points [total cholesterol $(\mathrm{TC}) \geq 6.2 \mathrm{mmol} / \mathrm{l} \quad(240 \mathrm{mg} / \mathrm{dl})$, triglyceride $\quad(\mathrm{TG}) \geq$ $2.3 \mathrm{mmol} / \mathrm{l}(200 \mathrm{mg} / \mathrm{dl})$, low-density lipoprotein cholesterol $(\mathrm{LDL}-\mathrm{C}) \geq 4.1 \mathrm{mmol} / \mathrm{l} \quad(160 \mathrm{mg} / \mathrm{dl})$, high-density lipoprotein cholesterol (HDL-C) $<1.0 \mathrm{mmol} / \mathrm{l} \quad(40 \mathrm{mg} /$ dl)] for adults and Experts Consensus for Prevention and
Treatment of Dyslipidemia in Children and Adolescents cut-offs points $[\mathrm{TC} \geq 5.2 \mathrm{mmol} / \mathrm{l}(200 \mathrm{mg} / \mathrm{dl}), \quad \mathrm{TG} \geq$ $1.7 \mathrm{mmol} / \mathrm{l}(150 \mathrm{mg} / \mathrm{dl}), \mathrm{LDL}-\mathrm{C} \geq 3.4 \mathrm{mmol} / \mathrm{l}(130 \mathrm{mg} / \mathrm{dl})$, HDL-C $<1.0 \mathrm{mmol} / \mathrm{l}(40 \mathrm{mg} / \mathrm{dl})]$ for pediatric patients were adopted. Dyslipidemia was defined by the presence of one or more abnormal serum lipid concentration.

Diabetic ketoacidosis (DKA) was defined by plasma glucose $\geq 13.9 \mathrm{mmol} / \mathrm{L}(250 \mathrm{mg} / \mathrm{dl})$, blood bicarbonate < $15 \mathrm{mmol} / \mathrm{L}$ and or $\mathrm{PH}<7.3$, and elevated level of ketones in urine or blood.

\section{Laboratory analysis}

The levels of glutamic acid decarboxylase antibody (GADA), islet cell antibody (ICA), and insulin antibody (IAA) were tested using the radioligand assay (Amon Biotechnology Company, Germany). The inter- and intra-assay variation coefficients of the GADA assay were $7.1-10.8 \%$ and $4.9-8.3 \%$, respectively. The sensitivity and specificity of the GADA assay were 82 and $98 \%$, respectively. The inter- and intra-assay variation coefficients of the IAA assay were $7.0-11.0 \%$ and $5.8-$ $8.3 \%$, respectively. The sensitivity and specificity of the IAA assay were 50 and $97 \%$, respectively. The inter- and intra-assay variation coefficients of the ICA assay were $4.2-9.8 \%$ and $4.0-9.9 \%$, respectively. The sensitivity and specificity of the ICA assay were $92.6 \%, 81.3 \%$, respectively.

$C$ peptide (CP) was determined by chemiluminescence (ADVIA Centaur, Acta Siemens, Munich, Germany). The inter- and intra-assay coefficients of the variation were $3.7-4.1 \%$ and $1.0-3.3 \%$, respectively. The normal range for C-peptide was $1.1-4.4 \mathrm{ng} / \mathrm{ml}$.

The hemoglobin A1c (HbA1c) levels were measured by automated liquid chromatography (HLC723G8, Tosoh). The inter- and intra-assay variation coefficients were less than 3 and $1 \%$, respectively.

In our hospital, we generally perform these tests for patients who can or have been diagnosed with T1D. Pancreatic islet autoantibodies are usually checked with fasting blood on the morning of the second day of hospitalization. The C-peptide test is usually done together with OGTT, usually when the fasting blood glucose is adjusted to below $8 \mathrm{mmol} / \mathrm{l}$ after blood glucose management.

\section{Statistical analysis}

Statistical analysis was performed with Statistical Product and Service Solutions (SPSS) version 24.0, Statistical analysis system (SAS) version 9.4 and GraphPad Prism 7. All $P$ values of less than 0.05 were regarded as being statistically significant. Participants' characteristics were defined using descriptive statistics. Continuous variables were presented as mean $\pm \mathrm{SD}$ or median (25th, 75th quartile). The categorical variables were expressed as 
number of cases and percentage of patients affected $n$ (\%). Two independent sample t-test for normal distributed variables, Mann-Whitney $U$ Test for nonparametric statistics and chi-square test for categorical variables were used to examine differences in demographic and clinical characteristics between young-onset and adultonset groups. Chi-square trend test was analyzed in SAS to observe linear correlation between proportion of overweight or obesity and year. The chart of the smoothed HbA1c mean versus age has been made in GraphPad Prism 7. For variables with a small percentage of missing data $(\leq 10 \%)$, we adopted the available-case analysis. For variables with a large percentage of missing data $(>10 \%)$, we adopted the multiple imputation methods.

\section{Results}

Clinical and demographic characteristics of all patients This analysis consisted of 1943 subjects [793 children and adolescents $(<18$ years) and 1150 adults $(\geq 18$ years)]with a mean age of $28 \pm 15$ years (range 6 months to 83 years), and a mean duration of $5 \pm 5$ years (range 0 day to 38 years, the duration of newly diagnosed patients were regarded as 0 day.). As shown in Table 1 and $50.6 \%$ of cases were male. The median age of patients at disease onset was 22 years old. Among 1943 patients with T1D, HbA1c values were obtainable in 1725 patients. The overall median (interquartile range) $\mathrm{HbA} 1 \mathrm{c}$ value was $10.3(8.2,12.5) \%$ or $89(66,113) \mathrm{mmol} / \mathrm{mol}$. Height and weight data were obtainable in 1250 patients. Overall, $16.9 \%$ of participants were overweight or obesity. Lipid values were obtainable in 1646 patients. The frequency of dyslipidemia was $37.8 \%$. The most frequent dyslipidemia was low high-density lipoprotein cholesterol (HDL) (29\%). We observed that $25.1 \%$ of patients presented with retinopathy. The proportion of patients with GADA, IAA and ICA were $28.1 \%, 6.4 \%$ and $21.6 \%$, respectively. Besides, $59.6 \%$ of newly diagnosed patients occurred diabetic ketoacidosis (DKA) at onset.

\section{The mean level of HbA1c in different age interval of T1D patients}

From Fig. 1, on the whole, the mean $\mathrm{HbA1c}$ value showed a downward trend with age, and the peak was in the age interval under 10 years. Between 21 and 51 years, the mean $\mathrm{HbA} 1 \mathrm{c}$ value seemed to be in a plateau period showing slow declining. There was also a second peak in the age interval $61-70$ years.

Table 1 Clinical and demographic characteristics of all patients $(N=1943)$

\begin{tabular}{|c|c|c|}
\hline Characteristic & Missing (\%) & n (\%) or Median (IQR) \\
\hline Male & $0(0)$ & $984(50.6)$ \\
\hline Current age(year) & $0(0)$ & $26(16,38)$ \\
\hline Age at onset(year) & $0(0)$ & $22(13,32)$ \\
\hline Duration(year) & $453(23.3)$ & $3(1,8)$ \\
\hline $\mathrm{HbA1c}(\%)$ & $218(11.2)$ & $10.3(8.2,12.5)$ \\
\hline $\mathrm{HbA} 1 \mathrm{c}(\mathrm{mmol} / \mathrm{mol})$ & $218(11.2)$ & $89(66,113)$ \\
\hline Overweight or Obesity & $693(35.7)$ & 211(16.9) \\
\hline Overweight & $693(35.7)$ & $171(13.7)$ \\
\hline Obesity & $693(35.7)$ & $40(3.2)$ \\
\hline Retinopathy & $82(4.2)$ & $468(25.1)$ \\
\hline Glutamic acid decarboxylase antibody & $772(39.7)$ & $329(28.1)$ \\
\hline Islet-cell antibodies & $779(40.1)$ & $252(21.6)$ \\
\hline Insulin antibodies & $779(40.1)$ & $74(6.4)$ \\
\hline Dyslipidemia & $297(15.3)$ & $623(37.8)$ \\
\hline High total cholesterol & $301(15.5)$ & $140(8.5)$ \\
\hline High triglyceride & $305(15.7)$ & 185(11.3) \\
\hline Low high-density lipoprotein cholesterol & $312(16.1)$ & $472(29.0)$ \\
\hline High low-density lipoprotein cholesterol & $288(14.8)$ & 116(7.1) \\
\hline DKA at onset in newly diagnosed patients & $52(11.5)$ & 239(59.6) \\
\hline Fasting C-peptide (ng/ml) & $214(11.0)$ & $0.3(0.1,0.5)$ \\
\hline 2-h C-peptide (ng/ml) & $214(11.0)$ & $0.8(0.3,1.3)$ \\
\hline
\end{tabular}

Comment: Values were presented as numbers of patients(percentages) or median (interquartile range). 


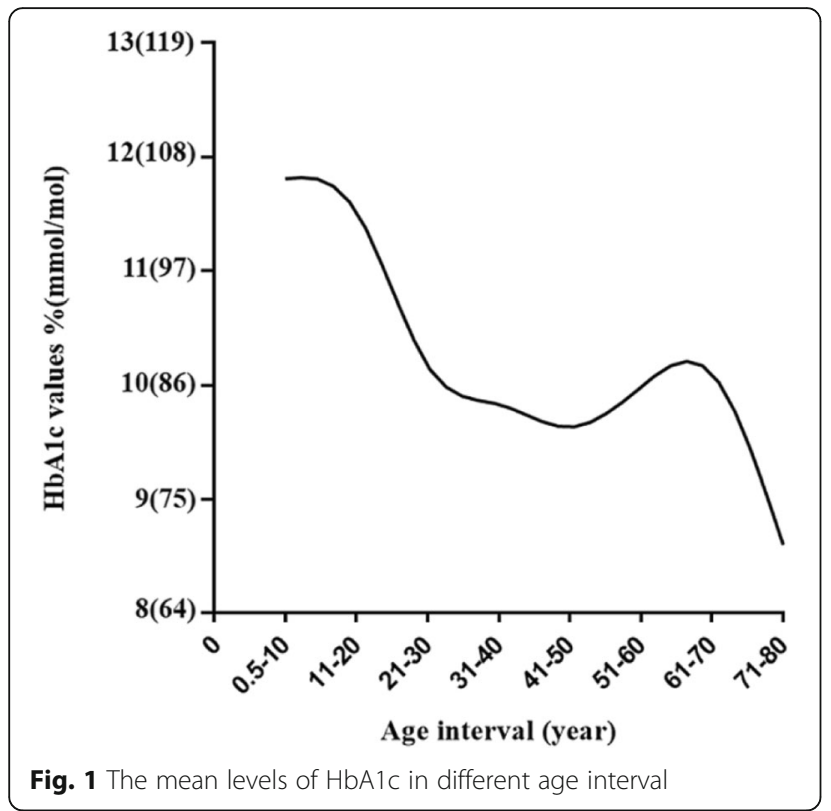

\section{Temporal changes in proportion of overweight and obesity}

The overall prevalence of overweight or obesity during 2012 and 2018 was $3.3 \%, 14.1 \%, 11.7 \%$, $20.2 \%, 10.8 \%, 16.0$ and $23.9 \%$, separately. Chisquare trend test showed that there was no significantly linear correlation between overall prevalence of overweight or obesity and year $(Z=0.1501, P=$ 0.699). As shown in Figs. 2 and 3, the prevalence of overweight or obesity in the adult-onset group is higher than that in the young-onset group (all $P<$ $0.05)$, and there is no difference between men and women (all $P>0.05$ ).
Comparison of characteristics in newly diagnosed youngonset and adult-onset patients

A total of 453 patients who were newly diagnosed in our hospital were selected to compare characteristics in young-onset and adult-onset group. As shown in Table 2, the prevalence of diabetes family histories in youngonset and adult-onset group were21.5 and $23.4 \%$, separately; but no significant difference was found in two groups. We observed that the adult-onset group had a higher proportion of overweight or obesity $(24.6 \%$ vs. $9.5 \%, P=0.002)$ than young-onset group. The youngonset participants had a higher median HbAlc value than the adult-onset patients $[12.9 \%(117 \mathrm{mmol} / \mathrm{mol})$ vs. $11.7 \%(104 \mathrm{mmol} / \mathrm{mol})], P<0.001)$. The frequency of diabetic ketoacidosis in young-onset group was significantly higher than that in adult-onset group ( $64.5 \%$ vs. $43.5 \%, P<0.001)$. The adult-onset group had significantly higher FCP and $2-\mathrm{h} \mathrm{CP}$ values $(0.4$ vs. $0.3 \mathrm{ng} / \mathrm{ml}$, $P<0.001 ; 0.9$ vs. $0.7 \mathrm{ng} / \mathrm{ml} P<0.001$, respectively), whereas lower proportion of undetectable/ detectable $\mathrm{C}$ peptide values ( $3 \%$ vs. $11 \%, P=0.003$ ) than young-onset patients. The overall frequency of dyslipidemia was $54.7 \%$ and was more in adult-onset group $(58.2 \%$ vs. $51.3 \%, P=0.212$ ). The frequency of high level of TC in young-onset group was significantly higher than that in the other group $(16.6 \%$ vs. $8.8 \%, P=0.029)$. The prevalence of GADA in adult-onset group was higher than that in young-onset group ( $33.7 \%$ vs. $23.3 \%, P=0.025)$.

\section{Discussion}

In this study, we retrospectively studied demographic and clinical features of T1D. We found that the study patients were characterized by poor blood glucose

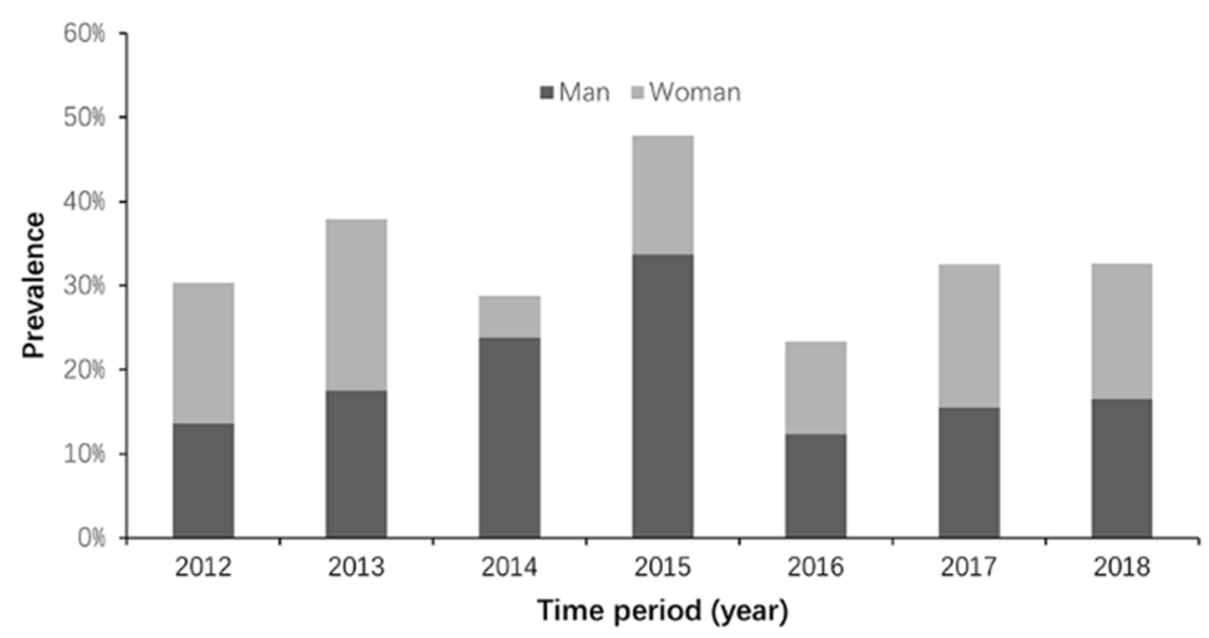

Fig. 2 Trends in the prevalence of overweight and obesity among T1D patients by gender (2012-2018) 


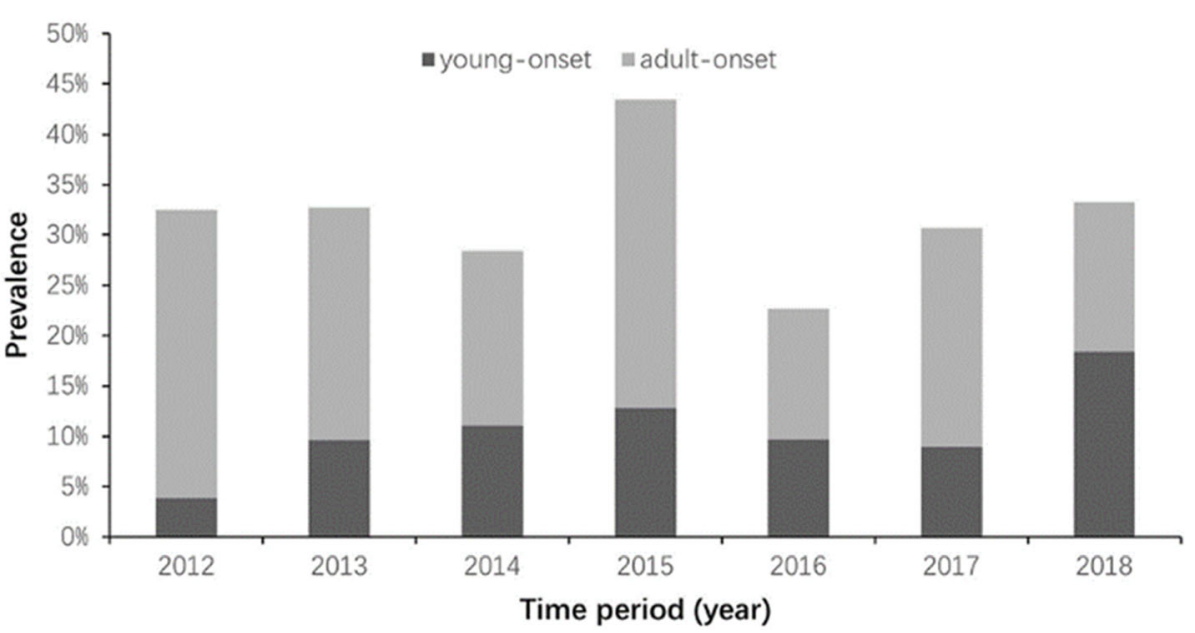

Fig. 3 Trends in the prevalence of overweight and obesity among T1D patients by age at onset (2012-2018)

Table 2 Comparison between new-diagnosed young-onset and adult-onset patients with T1D

\begin{tabular}{|c|c|c|c|}
\hline & $\begin{array}{l}\text { Young-onset } \\
(n=234)\end{array}$ & $\begin{array}{l}\text { Adult-onset } \\
(n=219)\end{array}$ & $P$-value \\
\hline Male (\%) & $120(51.3)$ & $141(64.4)$ & 0.006 \\
\hline $\begin{array}{l}\text { Age at } \\
\text { diagnosis(year) }\end{array}$ & $11(7,13)$ & $28(24,37)$ & $<0.001$ \\
\hline HbA1c (\%) & $12.9 \pm 2.4$ & $11.7 \pm 3.0$ & $<0.001$ \\
\hline $\mathrm{HbA} 1 \mathrm{c}(\mathrm{mmol} / \mathrm{mol})$ & $117 \pm 3$ & $104 \pm 9$ & $<0.001$ \\
\hline Diabetic ketoacidosis at onset & $148(64.5)$ & $91(43.5)$ & $<0.001$ \\
\hline Overweight or Obesity & $12(9.5)$ & $32(24.6)$ & 0.002 \\
\hline Overweight & $6(4.8)$ & $23(17.7)$ & 0.001 \\
\hline Obesity & $6(4.8)$ & $9(6.9)$ & 0.597 \\
\hline Glutamic acid decarboxylase antibody & $49(23.3)$ & $61(33.7)$ & 0.025 \\
\hline Islet-cell antibodies & $43(20.6)$ & $46(25.4)$ & 0.277 \\
\hline Insulin antibodies & $7(3.3)$ & $3(1.7)$ & 0.351 \\
\hline Dyslipidemia & $98(51.3)$ & 106(58.2) & 0.212 \\
\hline High total cholesterol & $31(16.6)$ & 16(8.8) & 0.029 \\
\hline High triglyceride & $36(18.8)$ & $28(15.4)$ & 0.412 \\
\hline Low high-density lipoprotein cholesterol & $82(42.9)$ & $92(51.4)$ & 0.118 \\
\hline High low-density lipoprotein cholesterol & $14(7.4)$ & $17(9.5)$ & 0.574 \\
\hline Urine acetone bodies & 177(77.0) & 151(71.9) & 0.230 \\
\hline Proteinuria & $32(14.0)$ & 28(13.4) & 0.890 \\
\hline Diabetes family history & $50(21.5)$ & $51(23.4)$ & 0.652 \\
\hline Fasting plasma glucose $(\mathrm{mmol} / \mathrm{l})$ & $6.6(5.2,8.0)$ & $7.3(5.6,10.0)$ & 0.051 \\
\hline Fasting C-peptide (ng/ml) & $0.3(0.2,0.5)$ & $0.4(0.2,0.7)$ & $<0.001$ \\
\hline 2-h C-peptide (ng/ml) & $0.7(0.4,1.1)$ & $0.9(0.6,1.8)$ & $<0.001$ \\
\hline Total cholesterol $(\mathrm{mmol} / \mathrm{l})$ & $4.0(3.4,4.9)$ & $4.1(3.3,4.8)$ & 0.785 \\
\hline Triglyceride (mmol/l) & $1.0(0.7,1.6)$ & $1.2(0.8,1.9)$ & 0.347 \\
\hline High-density lipoprotein cholesterol (mmol/l) & $1.1(0.9,1.4)$ & $1.0(0.9,1.2)$ & 0.006 \\
\hline Low-density lipoprotein cholesterol $(\mathrm{mmol} / \mathrm{l})$ & $2.3(1.9,2.9)$ & $2.5(2.0,3.3)$ & 0.057 \\
\hline Undetectable/ detectable C-peptide & $5 / 179$ & $19 / 166$ & 0.003 \\
\hline
\end{tabular}

Comments: Values were presented as numbers of patients(percentages), median (interquartile range), or means \pm SD 
control, high prevalence of acute and chronic complications (manifested by DKA, retinopathy, and dyslipidemia) and low detection rate of diabetes-related antibodies. On the whole, the mean HbAlc value showed a downward trend with age. There was no significantly linear correlation between overall prevalence of overweight or obesity and year from 2012 to 2018 . Compared with young-onset T1D, adult-onset patients comprised higher proportion of diabetes condition in the male gender, obesity or overweight and positivity of GADA, and better clinical manifestations.

\section{Comparison of Demographic and Clinical Features between this Population and Others}

In this analysis, we found that $59.6 \%$ of newly diagnosed patients occurred diabetic ketoacidosis (DKA) at onset. This was higher than that from another study in China (50.1\%)[23]. In terms of the methodological discrepancies between studies, our studies revealed a high prevalence of DKA, which may be related to poorer metabolic control. This study showed glycemic control was poor among patients with T1D, in whom the median level of HbAlc was $10.3 \%$ ( $89 \mathrm{mmol} / \mathrm{mol})$. It was similar to the published data from another cross-sectional study in China[24], which showed that mean HbA1c value was > $75 \mathrm{mmol} / \mathrm{mol}(9.0 \%)$. We also found that the mean HbA1c values were in a high level in all age interval and showed a downward trend with age (Fig. 1). A study[25] in the United States showed that the mean HbA1c values was $8.4 \%(68 \mathrm{mmol} / \mathrm{mol})$, and only a minority of patients with T1D achieved ADA goals for HbA1c. The differences of level of HbA1c values between different studies may be due to ethnicity, clinical characteristics, parental education, and income level, but the most important factor could be overall quality of care. Although all T1D patients in this study received insulin therapy, the specific form of insulin therapy is unclear (most T1D patients in our hospital are treated with basal-bolus therapy, a minority of patients are treated with insulin pump therapy). Overall, the high level of HbA1c values in this study mean that patients had higher risk of onset and progression of microvascular complications of $\mathrm{T} 1 \mathrm{D}[26,27]$. The result showed that the overall prevalence of retinopathy in our data was $25.2 \%$, which was higher than that reported in Swedish(21\%) [28], Norway (16\%)[29], USA (14\%) [30]and Germany (11\%) [31],regardless of shorter diabetic duration in this study. This may be resulted from poor glucose control, earlier and more frequent screening in our hospital, or clinical heterogeneity. Overt complications (proliferative retinopathy) remain rare in the adolescent population with T1D. Early indicators and pathological changes are clinically detectable in adolescents after 2- to 5-year disease duration[32, 33].
Weight change in TID is complex. Factors that may affect weight gain in patients with T1DM include the level of glycemic control, intensive insulin treatment, pattern of treatment, pubertal status, the presence of eating disorders and appearance of complications (such as thyroid disease or gastric disease)[34]. There are many studies that reported the prevalence of overweight and obesity of T1D, which varies from 21.0 to $53.8 \%$ in different countries with different criteria of overweight or obesity [34-37]. The current study of youth and adults showed that the prevalence of being overweight or obesity was $16.9 \%$. In contrast to other countries, the prevalence of overweight or obesity among patients with T1D in China was low. Another study[38] from China showed that in Chinese children and adolescents, mean BMI and the prevalence of overweight or obesity steadily increased from 19,991 to 2006. However, the most noticeable increase was in children from urban areas and those from higher income backgrounds, indicating a strong correlation between BMI and quality of life. In this study, the prevalence of overweight or obesity in T1D patients has not shown an upward trend in recent years (Fig. 2), which may suggest that there is still much room for improvement in the quality of care for T1D patients in China.

Dyslipidemia is a common concomitant disease of T1D, which is very related to glucose control. The overall prevalence of dyslipidemia among patients with T1D in this study was $37.8 \%$, which was higher than that found in Germany at 28.6\%[39] and lower than that in Korean at $37.9 \%[40]$. In contrast, the prevalence in the present study was much lower than that found in Bangladesh, which reported the overall prevalence of dyslipidemia were $65 \%$ in youth with T1D [41]. Also, a higher prevalence was found in Brazilian which reported that the prevalence of dyslipidemia in young patients was72.5\%[42]. The wide range of prevalence in various studies may be due to differences of treatment level.

Since this study was a retrospective analysis, data was limited about protein tyrosine phosphatase 2 auto- antibody (IA-2 A) and zinc transporter- 8 autoantibody (ZnT8A). Therefore, it is a pity that we only analyzed the proportion of GADA, ICA, IAA. We observed that the prevalence of GADA, ICA, IAA in the present study were $28.1 \%, 22.8 \%$ and $2.6 \%$, respectively, which were extremely lower than results reported in other countries [43-45]. A study from China by Xiao et al. showed that the positive rate of GADA was $52.2 \%$, IAA was $23.9 \%$, and ICA was $14.3 \%$. Another study[46] from China showed that the prevalence of GADA was $56.3 \%$ at diagnosis, decreasing to $50.5 \%$ one year later, and $43.3 \% 3-$ 5 years later. The reported prevalence of these autoantibodies in T1D may vary greatly depending on disease duration, age of onset, antibody assay method and so on. 
One possibility for the low prevalence of islet-related antibodies in this study is that other autoantibodies yet to be included maybe contributory. Another possibility is the low genetic susceptibilities in this population. Diabetes-related autoantibodies appeared in people with an increased genetic risk of T1D[47]. A study showed that the frequency of GADA is only $30-40 \%$ in Asian T1DM patients[48]. It attributed this difference to the fact that autoimmune-mediated $\beta$-cell destruction is less common in Asian patients. Besides, the older age of patients in this study maybe associated with the low prevalence of antibodies. A study demonstrated that with the increase of the age of onset, the newly diagnosed patients without any islet autoantibodies also increased[49]. Besides, compared with patients over 15 years old at onset, IAA was more common in children under 5 years old who developed T1D[49].

\section{Comparison of clinical features in young-onset and adult- onset patients}

It was generally accepted that TID in children were considered to have acute onset with classical symptoms of diabetes, while in adults, the onset of T1D can be more variable and have a better residual beta-cell function. In the analysis of 453 newly diagnosed patients, we observed that adult-onset patients accounted for $48.3 \%$. Adult-onset patients comprised better islet function reflected by FCP and 2-h CP. This result was in line with the results of the Diabetes Control and Complications Trial study and other subsequent studies[50-52]. It should be noted that the median fasting $\mathrm{C}$-peptide level in young-onset group was $0.3 \mathrm{ng} / \mathrm{ml}$, which was lower than a report from the USA (median random serum Cpeptide of children was $0.4 \mathrm{ng} / \mathrm{ml}$ ). Besides, the current study found that patients with the adult-onset group had lower median HbA1c levels and incidence of DKA at disease onset, which indicated that residual $\beta$-cell function was better, clinical manifestation was less severe, or hyperglycemia lasted shorter before diagnosis. Different from the traditional view that autoimmune disease are mostly women, T1D is even characterized by a clear male predominance in diabetes for new cases in Caucasians[53]. Similar to previous findings, we found the male excess in present population. In addition, adultonset group had higher proportion of male patients than young-onset group, agreeing with other studies in China $[23,24]$. As previously reported, studies had shown that the adult patients were most frequently tested positive for GADA[54], which indicated that very young patients tend to mount a weak antibody response to GADA and that the intensity of the GADA response increases with age[55].

The limitation of this study is the fact that this study is a retrospective and hospital-based study from one center in Henan province, so the representativeness of the research results is not as good as that of multicenters. Besides, due to the limitations of clinical diagnosis, some younger patients could have a monogenic diabetes, or the older subjects could have maturity-onset diabetes of youth (MODY). It is possible that some patients diagnosed as T1D may actually have T2D if studied further. Last but not least, as the value of the variables of interest were not measured or recorded for all subjects in the analysis, there were lots of missing data, especially the data of BMI and islet-related antibodies. Although available-case analysis and multiple imputation were adopted to address the presence of missing data, these approaches can lead to biased estimates of statistics.

\section{Conclusions}

In conclusion, despite the limitations of research design and data analysis, our data indicated that patients with T1D in this area were characterized by poor overall blood glucose control, high prevalence of diabetic ketoacidosis, dyslipidemia and diabetic retinopathy, and low prevalence of islet-related antibodies, and overweight or obesity. Compared with young-onset patients, adultonset patients with T1D were not uncommon and had better clinical manifestations at disease onset than young-onset patients. This may have some guiding effects on the clinic. Any findings related to BMI and autoantibodies should be considered strictly exploratory due to excessive missing data.

\section{Abbreviations}

GADA: Glutamic acid decarboxylase; ICA: Islet-cell antibodies; IAA: Insulin antibodies; TC: Total cholesterol; TG: Triglyceride; HDL-C: High-density lipoprotein cholesterol; LDL-C: Low-density lipoprotein cholesterol;

FCP: Fasting serum C-peptide; 2-h CP: 2-h postprandial serum C-peptide

\section{Acknowledgements}

We acknowledge all members of this study group. We also gratefully acknowledge Prof. LI who organized and conducted this project with us. We apologize to all those authors whose work on this subject has not been cited owing to space constraints.

\section{Authors' contributions}

YLG and $L X L$ designed the study and drafted the manuscript. YLG and YGX searched the literature, reviewed the literature, screened the record, performed the statistical analysis. All authors contributed to data review and interpretation and manuscript revision. All authors have read and approved the final manuscript.

\section{Funding}

This research did not receive any specific grant from funding agencies in the public, commercial, or not-for-profit sectors.

\section{Availability of data and materials}

The data that support the findings of this study are available from the authors and will be shared upon reasonable request. 


\section{Declarations}

\section{Ethics approval}

The study was carried out in compliance with the declaration of Helsinki. The study was approved by the Institutional Review Board of the First Affiliated Hospital of Zhengzhou University (Number: 2020-KY-417). Because this was a retrospective observational study, and de-identified information was used for the analysis, informed consents were waived as part of the Institutional Review Board of the First Affiliated Hospital of Zhengzhou University approval.

\section{Consent for publication}

Not applicable.

\section{Competing interests}

The authors declare there are no conflicts of interest.

\section{Author details}

${ }^{1}$ Department of Endocrinology, The First Affiliated Hospital of Zhengzhou University, 450052 Zhengzhou, Henan, China. ${ }^{2}$ Department of Cardioangiology, The First Affiliated Hospital of Zhengzhou University, 450052 Zhengzhou, Henan, China.

Received: 10 January 2021 Accepted: 17 June 2021

\section{Published online: 28 June 2021}

\section{References}

1. Eisenbarth GS: Type I diabetes mellitus. A chronic autoimmune disease. N Engl J Med 1986, 314(21):1360-1368.

2. Writing Group for the SfDiYSG, Dabelea D, Bell RA, D'Agostino RB, Jr., Imperatore G, Johansen JM, Linder B, Liu LL, Loots B, Marcovina S et al: Incidence of diabetes in youth in the United States. JAMA 2007, 297(24): 2716-2724.

3. Patterson CC, Dahlquist GG, Gyurus E, Green A, Soltesz G, Group ES: Incidence trends for childhood type 1 diabetes in Europe during 1989-2003 and predicted new cases 2005-20: a multicentre prospective registration study. Lancet 2009, 373(9680):2027-2033.

4. Harjutsalo V, Sjoberg L, Tuomilehto J: Time trends in the incidence of type 1 diabetes in Finnish children: a cohort study. Lancet 2008, 371(9626):17771782.

5. Group DP: Incidence and trends of childhood Type 1 diabetes worldwide 1990-1999. Diabet Med 2006, 23(8):857-866.

6. Parviainen A, But A, Siljander H, Knip M, Finnish Pediatric Diabetes R: Decreased Incidence of Type 1 Diabetes in Young Finnish Children. Diabetes Care 2020, 43(12):2953-2958

7. Gong C, Meng X, Saenger P, Wu D, Cao B, Wu D, Wei L: Trends in the incidence of childhood type 1 diabetes mellitus in Beijing based on hospitalization data from 1995 to 2010. Horm Res Paediatr 2013, 80(5):328334 .

8. Zhao Z, Sun C, Wang C, Li P, Wang W, Ye J, Gu X, Wang X, Shen S, Zhi D et al: Rapidly rising incidence of childhood type 1 diabetes in Chinese population: epidemiology in Shanghai during 1997-2011. Acta Diabetol 2014, 51(6):947-953.

9. Fu JF, Liang L, Gong CX, Xiong F, Luo FH, Liu GL, Li P, Liu L, Xin Y, Yao H et al: Status and trends of diabetes in Chinese children: analysis of data from 14 medical centers. World J Pediatr 2013, 9(2):127-134.

10. Hermann R, Knip M, Veijola R, Simell O, Laine AP, Akerblom HK, Groop PH, Forsblom C, Pettersson-Fernholm K, llonen J et al: Temporal changes in the frequencies of HLA genotypes in patients with Type 1 diabetes-indication of an increased environmental pressure? Diabetologia 2003, 46(3):420-425

11. Vehik K, Hamman RF, Lezotte D, Norris JM, Klingensmith GJ, Rewers M, Dabelea D: Trends in high-risk HLA susceptibility genes among Colorado youth with type 1 diabetes. Diabetes Care 2008, 31(7):1392-1396.

12. American Diabetes A: 2. Classification and Diagnosis of Diabetes: Standards of Medical Care in Diabetes-2020. Diabetes Care 2020, 43(Suppl 1):S14-S31.

13. Chiang JL, Kirkman MS, Laffel LM, Peters AL, Type 1 Diabetes Sourcebook A: Type 1 diabetes through the life span: a position statement of the American Diabetes Association. Diabetes Care 2014, 37(7):2034-2054.

14. Weng J, Zhou Z, Guo L, Zhu D, Ji L, Luo X, Mu Y, Jia W, Group TDCS: Incidence of type 1 diabetes in China, 2010-13: population based study. BMJ 2018, 360:j5295
15. Battaglia M, Ahmed S, Anderson MS, Atkinson MA, Becker D, Bingley PJ, Bosi E, Brusko TM, DiMeglio LA, Evans-Molina C et al: Introducing the Endotype Concept to Address the Challenge of Disease Heterogeneity in Type 1 Diabetes. Diabetes Care 2020, 43(1):5-12.

16. Tosur M, Redondo MJ: Heterogeneity of Type 1 Diabetes: The Effect of Ethnicity. Curr Diabetes Rev 2018, 14(3):266-272.

17. Ilonen J, Lempainen J, Veijola R: The heterogeneous pathogenesis of type 1 diabetes mellitus. Nat Rev Endocrinol 2019, 15(11):635-650.

18. Karvonen M, Viik-Kajander M, Moltchanova E, Libman I, LaPorte R, Tuomilehto J: Incidence of childhood type 1 diabetes worldwide. Diabetes Mondiale (DiaMond) Project Group. Diabetes Care 2000, 23(10):1516-1526.

19. Park Y, Eisenbarth GS: Genetic susceptibility factors of Type 1 diabetes in Asians. Diabetes Metab Res Rev 2001, 17(1):2-11.

20. Williams R, Karuranga S, Malanda B, Saeedi P, Basit A, Besancon S, Bommer C, Esteghamati A, Ogurtsova K, Zhang P et al: Global and regional estimates and projections of diabetes-related health expenditure: Results from the International Diabetes Federation Diabetes Atlas, 9th edition. Diabetes Res Clin Pract 2020, 162:108072.

21. Alberti KG, Zimmet PZ: Definition, diagnosis and classification of diabetes mellitus and its complications. Part 1: diagnosis and classification of diabetes mellitus provisional report of a WHO consultation. Diabet Med 1998, 15(7):539-553.

22. Hother-Nielsen O, Faber O, Sorensen NS, Beck-Nielsen H: Classification of newly diagnosed diabetic patients as insulin-requiring or non-insulinrequiring based on clinical and biochemical variables. Diabetes Care 1988, 11(7):531-537.

23. Yang D, Deng H, Luo G, Wu G, Lin S, Yuan L, Xv M, Li S, Zhang X, Wu J et al: Demographic and clinical characteristics of patients with type 1 diabetes mellitus: A multicenter registry study in Guangdong, China. J Diabetes 2016, 8(6):847-853.

24. Huo L, Ji L, Deng W, Shaw JE, Zhang P, Zhao F, McGuire HC, KissimovaSkarbek K, Whiting D: Age distribution and metabolic disorders in people with Type 1 diabetes in Beijing and Shantou, China: a cross-sectional study. Diabet Med 2018, 35(6):721-728.

25. Foster NC, Beck RW, Miller KM, Clements MA, Rickels MR, DiMeglio LA, Maahs DM, Tamborlane WV, Bergenstal R, Smith E et al: State of Type 1 Diabetes Management and Outcomes from the T1D Exchange in 20162018. Diabetes Technol Ther 2019, 21(2):66-72.

26. Diabetes C, Complications Trial Research G, Nathan DM, Genuth S, Lachin J, Cleary P, Crofford O, Davis M, Rand L, Siebert C: The effect of intensive treatment of diabetes on the development and progression of long-term complications in insulin-dependent diabetes mellitus. N Engl J Med 1993, 329(14):977-986.

27. Aiello LP, Group DER: Diabetic retinopathy and other ocular findings in the diabetes control and complications trial/epidemiology of diabetes interventions and complications study. Diabetes Care 2014, 37(1):17-23.

28. Samuelsson U, Steineck I, Gubbjornsdottir S: A high mean-HbA1c value 315 months after diagnosis of type 1 diabetes in childhood is related to metabolic control, macroalbuminuria, and retinopathy in early adulthood-a pilot study using two nation-wide population based quality registries Pediatr Diabetes 2014, 15(3):229-235.

29. Carlsen S, Skrivarhaug T, Thue G, Cooper JG, Goransson L, Lovaas K, Sandberg S: Glycemic control and complications in patients with type 1 diabetes - a registry-based longitudinal study of adolescents and young adults. Pediatr Diabetes 2017, 18(3):188-195.

30. Beck RW, Tamborlane WW, Bergenstal RM, Miller KM, DuBose SN, Hall CA, Network TDEC: The T1D Exchange clinic registry. J Clin Endocrinol Metab $2012,97(12) \cdot 4383-4389$.

31. Hammes HP, Kerner W, Hofer S, Kordonouri O, Raile K, Holl RW, Group DPWS: Diabetic retinopathy in type 1 diabetes-a contemporary analysis of 8,784 patients. Diabetologia 2011, 54(8):1977-1984.

32. Cho YH, Craig ME, Hing S, Gallego PH, Poon M, Chan A, Donaghue KC: Microvascular complications assessment in adolescents with 2- to 5-yr duration of type 1 diabetes from 1990 to 2006. Pediatr Diabetes 2011, 12(8): 682-689.

33. Sochett E, Daneman D: Early diabetes-related complications in children and adolescents with type 1 diabetes. Implications for screening and intervention. Endocrinol Metab Clin North Am 1999, 28(4):865-882.

34. Pinhas-Hamiel O, Levek-Motola N, Kaidar K, Boyko V, Tisch E, MazorAronovitch K, Graf-Barel C, Landau Z, Lerner-Geva L, Frumkin Ben-David R: Prevalence of overweight, obesity and metabolic syndrome components in 
children, adolescents and young adults with type 1 diabetes mellitus. Diabetes Metab Res Rev 2015, 31(1):76-84.

35. Maffeis C, Birkebaek NH, Konstantinova M, Schwandt A, Vazeou A, Casteels K, Jali S, Limbert C, Pundziute-Lycka A, Toth-Heyn P et al: Prevalence of underweight, overweight, and obesity in children and adolescents with type 1 diabetes: Data from the international SWEET registry. Pediatr Diabetes 2018, 19(7):1211-1220.

36. Kaminski BM, Klingensmith GJ, Beck RW, Tamborlane WW, Lee J, Hassan K, Schatz D, Kollman C, Redondo MJ, Pediatric Diabetes C: Body mass index at the time of diagnosis of autoimmune type 1 diabetes in children. J Pediatr 2013, 162(4):736-740 e731.

37. Fellinger $P$, Fuchs $D$, Wolf $P$, Heinze $G$, Luger $A$, Krebs $M$, Winhofer $Y$ : Overweight and obesity in type 1 diabetes equal those of the general population. Wien Klin Wochenschr 2019, 131(3-4):55-60.

38. Cui Z, Huxley R, Wu Y, Dibley MJ: Temporal trends in overweight and obesity of children and adolescents from nine Provinces in China from 1991-2006. Int J Pediatr Obes 2010, 5(5):365-374.

39. Schwab KO, Doerfer J, Hecker W, Grulich-Henn J, Wiemann D, Kordonouri O, Beyer P, Holl RW, Diabetology DPVlotGWGfP: Spectrum and prevalence of atherogenic risk factors in 27,358 children, adolescents, and young adults with type 1 diabetes: cross-sectional data from the German diabetes documentation and quality management system (DPV). Diabetes Care 2006, 29(2):218-225

40. Kim SH, Jung IA, Jeon YJ, Cho WK, Cho KS, Park SH, Jung MH, Suh BK: Serum lipid profiles and glycemic control in adolescents and young adults with type 1 diabetes mellitus. Ann Pediatr Endocrinol Metab 2014, 19(4):191-196.

41. Zabeen B, Balsa AM, Islam N, Parveen M, Nahar J, Azad K: Lipid Profile in Relation to Glycemic Control in Type 1 Diabetes Children and Adolescents in Bangladesh. Indian J Endocrinol Metab 2018, 22(1):89-92.

42. Homma TK, Endo CM, Saruhashi T, Mori AP, Noronha RM, Monte O, Calliari LE: Dyslipidemia in young patients with type 1 diabetes mellitus. Arch Endocrinol Metab 2015, 59(3):215-219.

43. Trisorus $C$, Aroonparkmongkol S, Kongmanas HB, Sahakitrungruang T: Prevalence of islet autoantibodies in Thai juvenile-onset type 1 diabetes. Pediatr Int 2018, 60(11):1002-1007.

44. Alyafei F, Soliman A, Alkhalaf F, Sabt A, De Sanctis V, Elsayed N, Waseef R: Prevalence of beta-cell antibodies and associated autoimmune diseases in children and adolescents with type 1 diabetes (T1DM) versus type 2 diabetes (T2DM) in Qatar. Acta Biomed 2018, 89(S5):32-39.

45. Al-Abady HL, Mahdi NK, Al-Naama LM, Mahdi JK: The prevalence of autoantibodies among relatives for type 1 and 2 diabetic patients. J Pak Med Assoc 2016, 66(9):1064-1067.

46. Chao C, Huang G, Li X, Yang L, Lin J, Jin P, Luo SM, Zhang YY, Pan LL, Zhou ZG: Change of glutamic acid decarboxylase antibody and protein tyrosine phosphatase antibody in Chinese patients with acute-onset type 1 diabetes mellitus. Chin Med J (Engl) 2013, 126(21):4006-4012.

47. Kupila A, Keskinen P, Simell T, Erkkila S, Arvilommi P, Korhonen S, Kimpimaki $\mathrm{T}$, Sjoroos M, Ronkainen M, llonen J et al: Genetic risk determines the emergence of diabetes-associated autoantibodies in young children. Diabetes 2002, 51(3):646-651.

48. Lee YS, Ng WY, Thai AC, Lui KF, Loke KY: Prevalence of ICA and GAD antibodies at initial presentation of type 1 diabetes mellitus in Singapore children. J Pediatr Endocrinol Metab 2001, 14(6):767-772.

49. Andersson C, Larsson K, Vaziri-Sani F, Lynch K, Carlsson A, Cedervall E, Jonsson B, Neiderud J, Mansson M, Nilsson A et al: The three ZNT8 autoantibody variants together improve the diagnostic sensitivity of childhood and adolescent type 1 diabetes. Autoimmunity 2011, 44(5):394-405.

50. Steffes MW, Sibley S, Jackson M, Thomas W: Beta-cell function and the development of diabetes-related complications in the diabetes control and complications trial. Diabetes Care 2003, 26(3):832-836.

51. Picardi A, Visalli N, Lauria A, Suraci C, Buzzetti R, Merola MK, Manfrini S, Guglielmi C, Gentilucci UV, Pitocco D et al: Metabolic factors affecting residual beta cell function assessed by C-peptide secretion in patients with newly diagnosed type 1 diabetes. Horm Metab Res 2006, 38(10):668-672.

52. Bruno G, Cerutti F, Merletti F, Cavallo-Perin P, Gandolfo E, Rivetti M, Runzo C, Pinach S, Pagano G, Piedmont Study Group for Diabetes E: Residual betacell function and male/female ratio are higher in incident young adults than in children: the registry of type 1 diabetes of the province of Turin, Italy, 1984-2000. Diabetes Care 2005, 28(2):312-317.

53. Speigelman $\mathrm{M}$, Marks $\mathrm{HH}$ : Age and sex variations in the prevalence and onset of diabetes mellitus. Am J Public Health Nations Health 1946, 36:26-33.
54. Vandewalle CL, Falorni A, Svanholm S, Lernmark A, Pipeleers DG, Gorus FK: High diagnostic sensitivity of glutamate decarboxylase autoantibodies in insulin-dependent diabetes mellitus with clinical onset between age 20 and 40 years. The Belgian Diabetes Registry. J Clin Endocrinol Metab 1995, 80(3): 846-851.

55. Sabbah E, Savola K, Ebeling T, Kulmala P, Vahasalo P, llonen J, Salmela PI, Knip M: Genetic, autoimmune, and clinical characteristics of childhood- and adult-onset type 1 diabetes. Diabetes Care 2000, 23(9):1326-1332.

\section{Publisher's Note}

Springer Nature remains neutral with regard to jurisdictional claims in published maps and institutional affiliations.
Ready to submit your research? Choose BMC and benefit from:

- fast, convenient online submission

- thorough peer review by experienced researchers in your field

- rapid publication on acceptance

- support for research data, including large and complex data types

- gold Open Access which fosters wider collaboration and increased citations

- maximum visibility for your research: over $100 \mathrm{M}$ website views per year

At BMC, research is always in progress.

Learn more biomedcentral.com/submissions 